\title{
PERAN KEPEMIMPINAN KEUCHIK DALAM PEMBANGUNAN DI GAMPONG JAMBAK, KECAMATAN PANTE CEUREUMEN, KABUPATEN ACEH BARAT
}

\author{
Aduwina Pakeh \\ Fakultas Ilmu Sosial dan Ilmu Politik, Universitas Teuku Umar \\ aduwina@utu.ac.id
}

\begin{abstract}
The purpose of this research is to know and analyze the leadership of village head in development in Jambak village, Pante Ceureumen District, West Aceh Regency and to identify how the success rate of Jambak village development in terms of physical development and nonphysical development. The research method used is qualitative descriptive method with research focus among others development of education facilities, bridge facilities, road facilities, electricity facilities, training courses of village government institutions, PKK development courses, and the development of art and culture. Primary data sources in this study were village head, village secretary, community, and community leaders in Jambak village.The results obtained by the authors in showing the leadership of the village head in the development of the village of Jambak is still lacking and can not say good, because there is still a lot of work that includes physical development and non-physical development of Jambak village has not all been resolved properly. Like the construction of educational facilities that are still said to be quite good. Bridge facilities that have not been built all in accordance with community expectations. Road construction has not been fully resolved yet, electricity facilities are also a problem faced by Jambak villagers. In addition to the non-physical development of the village, the training of village institutions has been running but still ineffective to further improve the quality of village government officials, so that village government officials are more comfortable.
\end{abstract}

Keywords: Leadership, Village Head, Development, Village 


\section{PENDAHULUAN}

Indonesia memasuki era reformasi yang di tandai dengan bergantinya kekuasaan pemerintahan dari rezim orde baru ke orde reformasi pada tahun 1998, mengawali periode pemerintahannya dengan berbagai masalah yang melanda, mulai dari krisis multi dimensi yang melanda seluruh kawasan Asia Tenggara, memberantas korupsi kolusi dan nepotisme, serta melaksanakan agenda Nasional yang sangat penting yaitu pembangunan nasional yang adil dan merata dalam segala bidang di seluruh wilayah Indonesia.

Tuntutan reformasi yang menarik perhatian adalah tentang desentralisasi pemerintahan dan otonomi daerah. Maka secara langsung mengubah ruang lingkup kewenangan pemerintah di Indonesia, Pemerintah Pusat memberikan kewenangannya kepada pemerintah daerah untuk mengatur dan mengurus rumah tangga atau daerahnya sendiri. Tujuan dari otonomi daerah secara umum adalah untuk meningkatkan kualitas keadilan, demokrasi, dan kesejahteraan bagi seluruh unsur bangsa yang beragam di dalam bingkai Negara Republik Indonesia. Salah satu caranya adalah meningkatkan daya guna dan hasil guna penyelenggaraan pemerintahan di daerah, terutama dalam pelaksanaan pembangunan dan pelayanan kepada masyarakat serta untuk meningkatkan pembinaan kestabilan politik dan kesatuan bangsa.

Pemerintah Daerah sebagai perangkat Pemerintah Pusat dalam proses pembangunan untuk mewujudkan kesejahteraan masyarakat di daerah harus mampu mengakomodir, mengelola, dan memberdayakan sumber-sumber yang ada secara keseluruhan di daerahnya masing-masing, baik sumber daya alam yang ada maupun sumber daya manusia yang ada di daerah.

Dengan demikian salah satu bagian dalam sistem pembangunan daerah adalah penyelenggaraan pembangunan desa yang dilaksanakan oleh pemerintah desa yang merupakan pelaksana pembangunan "garis depan" dalam pemerintahan Indonesia sesuai dengan pelaksanaan Otonomi Daerah yang telah di amanatkan dalam Undang - undang Nomor 23 Tahun 2014 tentang pemerintahan daerah.

Berdasarkan Undang-undang Nomor 6 Tahun 2014 tentang Desa. Desa adalah kesatuan masyarakat hukum yang memiliki batas wilayah yang berwenang untuk mengatur dan mengurus urusan pemerintahan, kepentingan masyarakat setempat berdasarkan prakarsa masyarakat, hak asal usul, dan/atau hak tradisional yang diakui dan dihormati dalam sistem pemerintahan Negara Kesatuan Republik Indonesia.

Keuchik (Kepala Desa) dalam menjalankan tugasnya dibantu oleh perangkat gampong dan bertanggung jawab kepada bupati/walikota melalui sekretaris daerah Kabupaten/walikota. Pertanggung jawaban Keuchik kepada bupati/walikota melalui sekretaris daerah Kabupaten/kota adalah pertanggung jawaban administrative. Pengertian melalui bukan berarti Keuchik merupakan bawahan lansung sekretaris daerah, karena secarah struktural Keuchik berada langsung di bawah camat.

\section{KERANGKA DASAR TEORI Peran}

Peran adalah suatu perilaku seseorang yang diharapkan dapat membuat suatu perubahan serta harapan yang mengarah pada kemajuan, meskipun tidak selamanya sesuai dengan apa yang diharapkan dan sebagai tolak ukur seseorang sebagai seorang pemimpin apakah orang itu dapat meningkatkan kinerjanya dalam menjalankan tugas - tugas yang diberikan kepadanya sehingga akan membuat orang tersebut dapat memaksimalkan kinerja dalam menjalankan tugas - tugasnya. Peran didefinisikan dari masing - masing pakar diantaranya peran dapat diartikan sebagai perilaku yang diatur dan diharapkan dari seseorang dalam posisi tertentu. Pemimpin didalam sebuah organisasi mempunyai peran, setiap pekerjaan membawa harapan bagaimana penanggung peran beprilaku. Fakta bahwa organisasi mengindetifikasikan pekerjaan yang harus dilakukan dan perilaku peran yang diinginkan yang berjalan seiring pekerjaan tersebut juga mengandung arti bahwa harapan mengenai peran penting dalam mengatur perilaku bawahan 
menurut Veithzal Rivai (2006:148). Pendapat lain juga mengatakan mendefinisikan peran adalah suatu yang menjadi bagian atau pegangan pimpinan yang terutama dalam terjadinya sesuatu hal atau peristiwa (Poerwadarminta, 1991:753).

Dengan kata lain sesuatu yang merupakan hak dari seorang pimpinan dalam sebuah organisasi masyarakat dalam menghadapi masalah-masalah yang ada di daerah kekuasaannya, serta dalam Kamus Besar Bahasa Indonesia (2000:667) menegaskan bahwa peran adalah bagian dari tugas utama yang harus dilaksanakan. Kemudian menurut Gunawan (2003: 369) Peran berarti sesuatu yang menjadi bagian atau pemegang pimpinan yang terutama dalam terjadinya hal atau peristiwa. Adapun menurut suhardono menyatakan bahwa peran merupakan patokan, yang membatasi apa yang mesti dilakukan oleh seseorang yang menduduki suatu jabatan.

Adapun peran Keuchik didalam desa: Pertama motivasi, merupakan dorongan, rangsangan, pengaruh, atau stimulus yang diberikan seorang individu kepada individu lainnya sedemikian rupa, sehingga orang yang diberikn motivasi tersebut menuruti atau melaksanakan apa yang dimotivasikan secara kritis, rasional dan penuh tanggung jawab. Kedua, fasilitator adalah orang yang memberikan bantuan dalam memperlancar proses komunikasi sekelompok orang, sehingga mereka dapat memahami atau memecahkan masalah bersama-sama. Ketiga mobilisator yaitu orang yang mengarahkan atau menggerakkan untuk melakukan sesuatu yang berkaitan dengan sebuah pembangunan guna untuk kepentingan bersama.

Jadi, pemimpin itu ialah seorang yang memiliki satu atau beberapa kelebihan sebagai predisposisi (bakat yang dibawa sejak lahir), dan merupakan kebutuhan dari satu situasi atau zaman, sehingga dia mempunyai kekuasaan dan kewibawaan untuk mengarahkan dan membimbing bawahan. Dia juga mendapatkan pengakuan serta dukungan dari bawahannya, dan mampu menggerakkan bawahan ke arah tujuan tertentu. Jadi peran adalah suatu perilaku seseorang yang diharapkan dapat membuat suatu perubahan serta harapan yang mengarah pada kemajuan, meskipun tidak selamanya sesuai dengan apa yang diharapkan dan sebagai tolak ukur seseorang sebagai seorang pemimpin apakah orang itu dapat meningkatkan kinerjanya dalam menjalankan tugas - tugas yang diberikan kepadanya sehingga akan membuat orang tersebut dapat memaksimalkan kinerja dalam menjalankan tugas - tugasnya.

\section{Kepemimpinan}

Menurut Kartono (2011:57) pengertian kepemimpinan yaitu kegiatan atau seni mempengaruhi orang lain agar mau bekerjasama yang didasarkan pada kemampuan orang tersebut untuk membimbing orang lain dalam mencapai tujuan-tujuan yang diinginkan kelompok. Menurut Bafadal (2003:44) kepemimpinan adalah sebagai keseluruhan proses mempengaruhi, mendorong, menggerakkan, dan menuntun orang lain dalam proses kerja agar berpikir, bersikap, dan bertindak sesuai dengan aturan yang berlaku dalam rangka mencapai tujuan yang telah ditetapkan.

Selanjutnya Amirullah (2004:245) mendefinisikan kepemimpinan sebagai hubungan dimana seseorang (pemimpin) mempengaruhi orang lain untuk mau bekerja sama melaksanakan tugas-tugas yang saling berkaitan guna mencapai tujuan yang diinginkan pemimpin dan atau kelompok. Definisi tersebut menekankan pada permasalahan hubungan antara orang yang mempengaruhi (pemimpin) dengan orang yang dipengaruhi (bawahan).

Dari beberapa definisi yang telah disebutkan, penulis dapat memberi kesimpulan bahwa kepemimpinan merupakan orang yang memiliki kewenangan untuk memberi tugas, mempunyai kemampuan untuk mempengaruhi orang lain melalui pola hubungan yang baik guna mencapai tujuan yang telah ditentukan.

Kepemimpinan dalam konteks struktural tidak hanya terikat pada bidang atau sub bidang yang menjadi garapannya, tetapi juga oleh rumusan tujuan dan program pencapaiannya yang telah ditetapkan oleh pemimpin yang lebih tinggi posisinya. Setiap anggota harus melaksanakannya tanpa menyimpang. Sehingga dalam hal ini kepemimpinan diartikan sebagai 
proses pemberian motivasi agar orang-orang yang dipimpin melakukan kegiatan atau pekerjaan sesuai dengan program yang telah ditetapkan.

\section{Teori kepemimpinan}

Memahami teori-teori kepemimpinan sangat besar artinya untuk mengkaji sejauh mana kepemimpinan dalam suatu organisasi telah dapat dilaksanakan secara efektif serta menunjang kepada produktifitas organisasi secara keseluruhan. Dalam karya tulis ini akan dibahas tentang teori dan gaya kepemimpinan.

Seorang pemimpin harus mengerti tentang teori kepemimpinan agar nantinya mempunyai referensi dalam menjalankan sebuah organisasi. Beberapa teori tentang kepemimpinan antara lain: Kesatu, Teori Kepemimpinan Sifat (Trait Theory) Analisis ilmiah tentang kepemimpinan berangkat dari pemusatan perhatian pemimpin itu sendiri. Teori sifat berkembang pertama kali di Yunani Kuno dan Romawi yang beranggapan bahwa pemimpin itu dilahirkan, bukan diciptakan yang kemudian teori ini dikenal "The Greatma Theory". Dalam perkembangannya, teori ini mendapat pengaruh dari aliran perilaku pemikir psikologi yang berpandangan bahwa sifat-sifat kepemimpinan tidak seluruhnya dilahirkan akan tetapi juga dapat dicapai melalui pendidikan dan pengalaman. Sifat-sifat itu antara lain: sifat fisik, mental dan kepribadian. Kedua, Teori kewibawaan, pemimpin Kewibawaan merupakan faktor penting dalam kehidupan kepemimpinan, sebab dengan faktor itu seorang pemimpin akan dapat mempengaruhi perilaku orang lain baik secara perorangan maupun kelompok sehingga orang tersebut bersedia untuk melakukan apa yang dikehendaki oleh pemimpin. Ketiga, Teori kepemimpinan situasi, seorang pemimpin harus merupakan seorang pendiagnosa yang baik dan harus bersifat fleksibel, sesuai dengan perkembangan dan tingkat kedewasaan bawahan. Keempat, Teori kelompok, Agar tujuan kelompok (organisasi) dapat tercapai, harus ada pertukaran yang positif antara pemimpin dengan pengikutnya.

\section{Tipe dan Gaya Kepemimpinan}

Menurut Nasution (2004:199) Gaya Kepemimpinan adalah suatu cara yang digunakan pemimpin dalam berinteraksi dengan bawahannya. Gaya kepemimpinan ini pada gilirannya ternyata merupakan dasar dalam membeda-bedakan atau mengklasifikasikan tipe kepemimpinan.

Gaya kepemimpinan memiliki tiga pola dasar, yaitu: Kesatu, Gaya kepemimpinan yang berpola mementingkan pelaksanaan tugas secara efektif dan efesien, agar mampu mewujudkan tujuan secara maksimal; Kedua, Gaya kepemimpinan yang berpola mementingkan pelaksanaan hubungan kerja sama; dan Ketiga, Gaya kepemimpinan yang berpola mementingkan hasil yang dapat dicapai dalam rangka mewujudkan tujuan organisasi. Disini pemimpin menaruh perhatian yang besar dan memiliki keinginan yang kuat, agar setiap anggota berprestasi sebesar-besarnya.

\section{Bentuk Kepemimpinan}

Rivai (2007:4) mengutarakan bahwa "kepemimpinan resmi (formal) adalah seseorang yang ditunjuk sebagai pemimpin, atsas dasar keputusan dan pegangkatan resmi untuk memangku suatu jabatan dalam struktur organisasi dengan segala hak dan kewajiban yang melekat berkaitan dengan posisinya. Pola ini terlihat pada sebagian ketentuan yang mengatur hirarki organisasi dan biasanya tergambar dalm bagan organisasi”.

Lebih Lanjut Rivai (2007;5) menjelaskan kepemimpinan dapat dibagi menjadi beberapa hal yaitu: a) Tanggung Jawab yaitu kesanggupan seseorang dalam menyelesaikan pekerjaan yang diserahkan kepadanya dengan sebaik-baiknya dan tepat pada waktunya serta berani memikul resiko atas keputusan yang diambilnya atau tindakan yang dilakukannya. b) Supervisi yaitu suatu usaha menstimulir, mengkoordinir dan membimbing secara kontiniu seorang pekerja baik secara individual maupun secara kolektif, agar lebih mengerti dan lebih efektif dalam 
mewujudkan seluruh fungsi pekerja, sehingga dengan demikian mereka mampu dan lebih cakap berpartisipasi dalam masyarakat modern c) Inisiatif Yaitu kemampuan untuk mengevaluasi secara mandiri untuk mengambil kendali dalam suatu situasi sebelum orang lain bertindak dan sekaligus menerapkan strategy dalam memecahkan msalah yang sedang dihadapi

\section{Fungsi Kepemimpinan}

Fungsi artinya jabatan (pekerjaan) yang dilakukan atau kegunaan sesuatu hal atau kerja suatu bagian tubuh. Sedangkan fungsi kepemimpinan berhubungan langsung dengan situasi social dalam kehidupan kelompok atau organisasi masing-masing, yang mengisyaratkan bahwa setiap pemimpin berada di dalam dan bukan di luar siuasi itu. Menurut Kartono (2006:93), fungsi kepemimpinan adalah memandu, mamnuntun, membimbing, membangun, member atau membangunkan motivasi-motivasi kerja, mengemudikan organisasi, menjalin jaringan-jaringan komunikasi yang baik dan memberikan supervise/pengawasan yang efisien, dan membawa para pengikutnya kepada sasaran yang ingin dituju, sesuai dengan ketentuan waktu dan perencanaan.

Fungsi kepemimpinan merupakan gejala social, karena harus diwujudkan dalam interaksi antar individu di dalam situasi social suatu kelompok atau organisasi. Fungsi kepemimppinan memiliki dua dimensi seperti: Kesatu, Dimensi yang berkenaan dengan tingkat kemampuan mengarahkan (direction) dalam tindakan atau aktivitas pemimpin, yang terlihat pada tanggapan orang-orang yang dipimpinnya. Kedua, Dimensi yang berkenaan dengan tingkat dukungan (support) atau keterlibatan orang-orang yang dipimpin dalam melaksanakan tugas tugas pokok kelompok/organisasi, yang dijabarkan dan dimanifestasikan melalui keputusan-keputusan dan kebijaksanaan- kebijaksanaan pemimpin.

\section{Pembangunan}

Sebelum ditelaah tentang pembangunan desa, maka terlebih dahulu dikemukakan arti serta pengertian dasar dari pembangunan pada umumnya, menurut Tjokroamidjojo (2000:42) mengatakan bahwa pembangunan adalah didalam proses atau usaha - usaha perubahan sosial (sicial chenge) tersebut dapat berarti suatu usaha perubahan dan pembangunan dari keadaan dan kondisi masyarakat yang lebih baik.

Dalam melaksanakan pembangunan perlu adanya suatu usaha dan proses, menurut Khairuddin (2000:24) yang dinyatakan oleh Siagian pembangunan adalah rangkaian usaha yang secara sadar dilakukan. Artinya, keadaan yang lebih baik, yang didambakan oleh suatu masyarakat, serta pertumbuhan yang diharapkan akan terus berlangsung, tidak terjadi dengan sendirinya, apalagi secara kebetulan. Usaha atau proes pembangunan yang dilaksanakan oleh suatu Negara adalah tekad atau keinginan yang disusun berdasarkan pemikiran - pemikiran dan pertimbangan - pertimbangan secara luas. Usaha atau proses pembangunan terlihat dengan adanya kehendak untuk menentukan arahan - arahan sebagai pedoman dalam melaksanakan pembangunan tersebut.

Demi terwujudnya pembangunan yang berjalan dengan baik dalam suatu desa diperlukannya partisipasi dari masyarakat agar pembangunan tersebut dapat berjalan dengan lancar, menurut Siagian (2005:4) ada tujuh ide pokok pembangunan: Kesatu, Pembangunan merupakan suatu proses. Berarti pembangunan merupakan rangkaian kegiatan yang berlangsung secara bekelanjutan dan terdiri dari tahap - tahap yang disatu pihak bersifat independen akan tetapi dipihak lain merupakan bagian dari sesuatu yang tanpa akhir (never ending). Kedua, Pembanguanan merupakan upaya yang secara sadar ditetapkan sebagai sesuatu untuk dilaksanakan. Dengan kata lain, jika dalam rangka kehidupan seperti pembangunan, akan tetapi sebenarnya tidak ditetapkan secara sadar dan hanya terjadi secara sporadis atau insidental, kegiatan tersebut dapat dikategorikan sebagai pembangunan. Ketiga, Pembangunan dilaksanakan secara terencana, baik dalam arti jangka panjang, jangka menengah, jangka pendek. Dan seperti dimaklumi merencanakan berarti mengambil keputusan sekarang tentang 
hal - hal yang akan dilakukan pada jangka waktu tertentu di masa depan. Keempat, Rencana pembangunan mengandung makna pertumbuhan dan perubahan. Pertumbuhan dimaksudkan sebagai peningkatan kemampuan suatu negara bangsa harus bersikap antisipatif dan proaktif dalam menghadapi tututan situasi yang berbeda dari suatu jangka ke jangka waktu yang lain, terlepas apakah situasi berbeda itu dapat diprekdisikan sebelumnya atau tidak. Dengan kata lain suatu negara bangsa yang sedang membangun tidak akan puas jika hanya mampu mempertahankan status quo yang ada. Kelima, Pembangunan mengarah pada modernitas. Modernitas disini diartikan antara lain cara hidup yang baru akan lebih dari pada sebelumnya, cara berfikir yang rasional dan sistem budaya yang kuat tetapi fleksibel. Walaupun demikian perlu diingatkan bahwa konsep modernitas tidak identik dengan "cara hidup gaya barat". Setiap bangsa negara yang modern harus tetap mempertahankan jati dirinya yang bersumber dari nilainilai yang dipandang oleh negara bangsa yang bersangkutan. Bahwa ada aspek - aspek tersebut yang memerlukan penyesuaian karena tuntutan zaman, itu pun harus diakui dan dijadikan masukan dalam merumuskan strategi pembangunan yang akan ditempuh. Keenam, Modernitas yang ingin dicapai melalui berbagai kegiatan pembangunann perdefinisi multidemensional. Artinya, modernitas mencakup seluruh segi kehidupan berbangsa dan bernegara, yang dapat mengejawantah dalam bidang bidang politik, ekonomi, sosial budaya, serta pertahanan keamanan. Ketujuh, semua hal yang telah dibahas ditujukan kepada usaha pembinaan bangsa sehingga negara bangsa yang sejajar dengan bangsa - bangsa lain didunia karena mampu menciptakan situasi yang membuatnya berdiri sama tinggi dan duduk sama rendah dengan negara bangsa lain tersebut.

Proses pembangunan merupakan suatu perubahan sosial budaya, pembangunan menjadi suatu proses yang dapat bergerak maju atas kekuatan sendiri tergantung kepada manusia dan struktur sosialnya. Jadi, pembangunan bukan hanya yang dikonsepsikan sebagai usaha pemerintah belaka. Melainkan pembangunan tergantung dari proses emasipasi diri, dan suatu partisipasi kreatif dalam proses pembangunan.

\section{Pembangunan Desa}

Pendapat Marbun (2008:38) bahwa pembangunan desa merupakan usaha pembangunan dari masyarakat pada unit pemerintah terendah yang harus dilaksanakan dan dibina terus menerus, sistematis dan terarah sebagai satu kesatuan dengan pembangunan daerah dan nasional.

Menurut Siagian (2003:108) mendefinisikan bahwa pembangunan desa adalah keseluruhan proses rangkaian usaha-usaha yang dilakukan dalam lingkungan desa dengan tujuan untuk meningkatkan taraf hidup masyarakat desa serta memperbesar kesejahteraan dalam desa.

Senada pula yang disampaikan oleh Ndraha (2002:9) bahwa pembangunan desa adalah proses dengan mana usaha-usaha masyarakat desa yang bersangkutan dipadukan dengan usahausaha pemerintah, untuk meningkatkan taraf hidup masyarakat, mengintegrasikan kehidupan masyarakat desa ke dalam kehidupan bangsa yang memungkinkan mereka untuk memberikan sumbangan sepenuhnya kepada pembangunan nasional.

\section{METODOLOGI PENELITIAN}

Jenis penelitian ini adalah penelitian deskriptif kualitatif. Penelitian deskriptif adalah penelitian yang memaparkan dan bertujuan memberikan gambaran serta menjelaskan dari variabel yang diteliti. Sedangkan menurut Moleong (2007:6) mengemukakan bahwa deskriptif adalah data yang dikumpulkan berupa kata-kata, gambar, dan bukan angka-angka.

Fokus penelitian ini ada dua iaitu: pertama, bagaimana peran kepemimpinan Keuchik dalam pembangunan fisik gampong seperti pembangunan sarana pendididkan, sarana jambatan, sarana jalan dan sarana listrik; dan Kedua, bagaimana peran kepemimpinan Keuchik dalam 
pembangunan non fisik gampong seperti kursus atau latihan pembinaan lembaga pemerintahan gampong, kursus atau latihan pembinaan PKK dan pembangunan seni budaya.

Informan dalam penelitian ini pada tahap awal adalah Sekretaris Gampong Jambak sebagai Key Imporman. Informan selanjutnya mengalir saja sesuai data yang diperlukan seperti tokoh masyarakat dan masyarakat di gampong Jambak kecamatan Pante Ceureumen Kabupaten Aceh Barat. Sedangkan analisis data dalam penelitian ini, data diperoleh dari berbagai sumber dengan menggunakan teknik pengumpulan data yang bermacam-macam (triangulasi), dan dilakukan secara terus-menerus sampai datanya mengakibatkan variasi data yang tinggi. Data yang diperoleh umumnya data kualitatif (Sugiyono, 2013).

\section{HASIL PENELITIAN DAN PEMBAHASAN}

\section{Gambaran Umum Lokasi Penelitian}

Luas wilayah gampong Jambak $\pm 2000 \mathrm{Ha}$, merupakan salah satu gampong dalam Kecamatan Pante Ceureumen, Kabupaten Aceh Barat. Gampong Jambak berjarak 69 KM dari Kota Meulaboh sebagai pusat Pemerintahan Kabupaten.

Gampong Jambak memiliki batasan-batasan sebagai berikut:

$\begin{array}{ll}\text { Sebelah Utara } & \text { : Kabupaten Nagan Raya } \\ \text { Sebelah Selatan } & \text { : Gampong Canggei } \\ \text { Sebelah Barat } & \text { : Gampong Keutambang } \\ \text { Sebelah Timur } & \text { : Gampong Sikundo }\end{array}$

Gampong Jambak merupakan salah satu gampong paling hujung dalam kecamatan Pante Ceureumen sebelum gampong Sikundo. Gampong Jambak membawahi 4 Dusun dengan jumlah penduduk 375 Jiwa, terdiri dari 186 jiwa penduduk laki-laki dan 194 Jiwa penduduk perempuan.

\section{Hasil Penelitian \\ Peran kepemimpinan Keuchik dalam pembangunan fisik gampong Sarana Pendidikan}

Pembangunan yang telah dilakukan Keuchik dalam segi pembangunan sarana pendidikan cukup berhasil selama kepemimpinan Keuchik selama ini. Bagaimana tidak, gampong Jambak memiliki fasilitas pendidikan yang sangat memadai, mulai dari gedung PAUD (Pendidikan Anak Usia Dini), Gedung Sekolah Dasar (SD) dan juga memiliki Gedung Sekolah Lanjutan Tingkat Pertama (SLTP). Kedua sekolah itu berstatus Negeri.

Maka dalam peran kepemimpinan Keuchik dalam pembangunan sarana dan prasarana pendidikan cukup baik dalam masa kepemimpinannya, karena sudah bisa menghasilkan gedung sekolah dasar tambahan dan gedung pendidikan anak usia dini, namun harus ditingkatkan lagi terutama dalam kecakapan Keuchik selaku pelaksana pembangunan yang ada di gampong, untuk mengarahkan proses-proses pembangunan sarana dan prasarana pendidikan agar lebih diperbanyak lagi guna dapat menampung seluruh anak-anak PAUD (Pendidikan Anak Usia Dini) serta anak-anak Sekolah Dasar yang telah cukup umur dan memang mempunyai niat untuk bersekolah, agar tidak kalah dari anak-anak yang ada di kota. Dengan kata lain Keuchik harus lebih mengambil sikap untuk bisa lebih memajukan atau bisa mengusulkan pembangunan gedung-gedung serta rumah untuk para guru-guru yang bertugas di Gampong Jambak.

\section{Sarana Jambatan}

Pembangunan yang telah dilakukan Keuchik dalam segi pembangunan sarana dan prasarana jembatan kurang berhasil. Pembangunan jembatan belum berjalan dengan baik, karena hanya berdiri 1 dari 2 jembatan yang diinginkan oleh masyarakat. Guna lebih memberi kenyamanan kepada masyarakat untuk tidak khawatir lagi apabila menggunakan jembatan lama yang menggunakan balok kayu yang rentan roboh dimakan usia. 
Walaupun sudah berhasil membangun satu jembatan yang sekarang berdiri kokoh di gampong Jambak. Namun memang proses pengadaan pembangunan jembatan dan proyek pengerjaaan jembatan sangat lamban, jadi selaku Keuchik harus lebih peka dan memprioritaskan proses pembangunan jembatan yang memang diinginkan oleh warga masyarkat Gampong Jambak.

\section{Sarana Jalan}

Pembangunan yang telah dilakukan Keuchik dalam segi pembangunan sarana dan prasarana jalan cukup berhasil selama kepemimpinan periode ini. Namum memang selama pengamatan di lapangan pembangunan jalan belum benar-benar $100 \%$ selesai. Dapat disimpulkan bahwa peran kepemimpinan Keuchik dalam pembangunan sarana jalan sudah berjalan cukup baik. Namum belum semuanya dapat terselesaikan. Jalan utama menuju gampong Jambak sudah bisa dilalui dengan mudah baik menggudakan roda dua maupun roda empat. Walaupun demikian, Keuchik berserta segenap perangkatnya harus lebih giat berusaha ke depan agar jalan utama tersebut dapat di aspal, sehingga transportasi masyarakat gampong Jambak lebih mudah dan alur distribusi kebutuhan masyarakat dan peniagaan hasil pertanian masyarakat lebih mudah dijangkau.

\section{Sarana Listrik}

Pembangunan yang telah dilakukan Keuchik dalam segi pembangunan sarana dan prasarana listrik berjalan stagnan, maksudnya tidak ada kemajuan yang berarti. Problema listrik di gampong Jambak sama seperti yang dialami oleh gampong-gampong lain dalam kecamatan Pante Ceureumen. Meskipun sudah dialiri listrik dari Perusahaan Listrik Negara (PLN) Biro Meulaboh, namun masih sering terjadi pemadaman listrik yang terjadi secara tiba-tiba dan dalam intensitas yang tinggi.

Diketahui bahwa selama kepemimpinan Keuchik dalam pembangunan sarana listrik bisa diktkan gagal karena tidak ada pembangunan yang berjalan dengan bik, walaupun sempat ada masuknya proyek PLTA dan pada akhinya belum menunjukkan hasil yang memuaskan. Pembangunan sarana dan prasarana listrik yang dilihat di lapangnan memang tidak sangat baik, diketahui bahwa dari masa ke masa tongkat kepemimpinan Keuchik masalah listrik hampir tidak bisa teratasi.

\section{Peran kepemimpinan Keuchik dalam pembangunan non fisik gampong Kursus atau Latihan Pembinaan Lembaga Pemerintahan Gampong}

Kursus merupakan termasuk pendidikan nonformal. Kursus merupakan suatu kegiatan belajar-mengajar seperti halnya sekolah. Perbedaannya adalah bahwa kursus biasanya diselenggarakan dalam waktu pendek dan hanya untuk mempelajari satu keterampilan saja. Begitu halnya yang dilakukan oleh Keuchik mengharapkan selalu adanya kursus atau pelatihan pembinaan lembaga pemerintahan gampong yang memang kita tahu aparatur-aparatur gampong itu tidak sama seperti aparatur yang ada di kelurahan.

Diketahui bahwa selama peran kepemimpinan Keuchik dalam rangka pelatihan lembaga pemerintahan gampong masih kurang. Jadi Keuchik harus memainkan perannya lagi untuk lebih sering mengadakan pelatihan atau kursus pembinaan aparatur gampong. Selaku pemimpin tertinggi di sebuah gampong, Keuchik harus memperhatikan lagi aparat pemerintahan gampong yang merupakan bawahannya langsung.

Apalagi system perencanaan dan penggangaran serta pelaporan dana desa sekarang sudah menggunakan aplikasi, sehingga aparatur gampong sangat membutuhkan pemahaman terkait informasi dan teknologi (IT). Sehingga bisa memenuhi kebutuhan yang diperlukan oleh pemerintah yang lebih tinggi. 


\section{Latihan Pembinaan PKK}

Peran kepemimpinan Keuchik dalam usaha mengadakan pelatihan pembinaan PKK harus lebih ditingkatkan lagi. Memang pelatihan atau kursus sudah ada, namun dirasakan masih kurang. Karena selama ini pelatihan hanya dilakukan 1 tahun sekali, maka dari itu 10 kegiatan inti PKK kurang berjalan dengan baik.

Keuchik harus lebih tanggap lagi mengenai keanggotaan organisasi wanita Gampong Jambak dalam organisasi PKK, dengan lebih aktif lagi untuk melakukan usaha memberikan pelatihan atau kursus yang bekerjasama dengan Pemerintah Kecamatan mahupun Kabupaten Aceh Barat guna lebih memajukan wanita-wanita yang ada di pedesaan agar tidak selalu tertinggal mengenai wawasan dan ilmu-ilmu tentang organisasi kewanitaan seperti PKK

\section{Pembangunan Seni Budaya}

Meningkatkan partisipasi masyarakat dalam pengkajian potensi sosial budaya masyarakat khususnya seni budaya lokal Gampong Jambak sebagai modal sosial pembangunan, serta memetakan peluang dan ancaman dalam rangka melakukan perencanaan, pengawasan, pelaksanaan, pengendalian, evaluasi dan tindak lanjut serta pertanggungjawaban kegiatan masyarakat gampong. Memberdayakan kelompok-kelompok masyarakat pengembang seni budaya lokal.

Peran kepemimpinan Keuchik dalam segi pembangunan seni budaya sangat baik selama ini, terutama dalam hal tari-tarian. Selaku pemimpin dalam gampong memang benar-benar memperhatikan mengenai aspek pembangunan seni budaya. Jadi pembangunan seni budaya terbentuk dan berjalan dengan baik atas kerja sama bersama masyarakat.

\section{Pembahasan}

Berdasarkan hasil penelitian yang dilakukan maka dalam peran kepemimpinan Keuchik dalam pembangunan sarana pendidikan sudah berjalan dengan baik. Karena sudah berhasil membangun gedung sekolah. Jadi selaku Keuchik harus bisa menggunakan peranannya lagi terutama dalam kecakapan Keuchik selaku pelaksana pembangunan yang ada di gampong, untuk mengarahkan proses-proses pembangunan sarana dan prasarana pendidikan agar lebih diperbanyak lagi guna dapat menampung seluruh anak-anak PAUD (Pendidikan Anak Usia Dini) serta anak-anak Sekolah Dasar yang telah cukup umur dan memang mempunyai niat untuk bersekolah, agar tidak kalah dari anakanak yang ada di kota.

Tentang peran kepemimpinan Keuchik dalam pembangunan sarana dan prasarana jembatan, bisa dikatakan lamban. Walaupun sudah berhasil membangun satu jembatan yang sekarang berdiri kokoh di gampong Jambak. Namun memang proses pengadaan pembangunan jembatan dan proyek pengerjaaan jembatan sangat lamban, jadi selaku kepala desa harus lebih peka dan memprioritaskan proses pembangunan jembatan yang memang diinginkan oleh warga masyarkat Gampong Jambak. Dengan kata lain harus lebih tegas dalam melakukan perencanaan dan pengawasan terhadap pembangunan jembatan yang selanjutnya.

Dapat disimpulkan bahwa peran kepemimpinan Keuchik dalam pembangunan sarana jalan sudah berjalan cukup baik, namum belum semuanya dapat terselesaikan. Jadi selaku Keuchik harus bisa lebih aktif dan cakap lagi dalam proses membangun sarana dan prasarana jalan. Dan juga Keuchik harus lebih bekerja keras lagi dalam memprioritaskan proses pembangunan jalan yang memang diinginkan oleh warga masyarkat Gampong Jambak. Dengan kata lain harus lebih berusaha lagi dalam melakukan perencanaan dan pengawasan terhadap pembangunan jalan yang ada di Gampong.

Diketahui bahwa selama peran kepemimpinan Keuchik dalam pembangunan sarana listrik bisa dikatakan tidak berhasil karena tidak ada pembangunan yang berjalan sesuai dengan harapan masyarkat gampong itu sendiri. Walaupun sempat ada masuknya proyek PLTA dan pada akhinya gagal juga. Pembangunan sarana dan prasarana listrik yang dilihat di lapangan 
memang tidak sangat baik, diketahui bahwa dari masa ke masa tongkat kepemimpinan Keuchik masalah listrik hampir tidak bisa teratasi.

Kepemimpinan Keuchik perannya dalam rangka pelatihan lembaga pemerintahan gampong masih kurang, jadi Keuchik harus memainkan perannya lagi untuk lebih sering mengadakan pelatihan atau kursus pembinaan aparat gampong. Selaku Keuchik harus memperhatikan lagi aparat pemerintahan gampong yang merupakan bawahannya langsung.

Peran kepemimpinan Keuchik dalam mengadakan pelatihan atau kursus PKK harus lebih ditingkatkan lagi. Memang pelatihan atau kursus sudah ada, namun dirasakan masih kurang. Jadi Keuchik harus lebih tanggap lagi mengenai keanggotaan organisasi wanita Gampong Jambak dalam organisasi PKK, dengan lebih aktif lagi memberikan pelatihan atau kursus, yang bekerjasama dengan Pemerintah Daerah Kabupaten Aceh Barat guna lebih memajukan wanitawanita yang ada di pedesaan agar tidak selalu tertinggal mengenai wawasan dan ilmu-ilmu tentang organisasi kewanitaan seperti PKK.

\section{SIMPULAN DAN SARAN}

\section{A. Simpulan}

Peran Kepemimpinan Keuchik dalam Pembangunan fisik Gampong Jambak di Kecamatan Pante Ceureumen Kabupaten Aceh Barat. Seperti pembangunan sarana pendidikan yang masih dikatakan cukup, karena masih jauh dari kata baik dikarenakan masih kurangnya gedung sekolah, rumah dinas untuk para guru tim pengajar yang memang kebanyakan bukan penduduk asli dari warga gampong Jambak.

Sarana jembatan yang belum terbangun semua sesuai dengan harapan masyarakat, yang memang mengharapkan agar semua jembatan besi segera dibangun agar lebih mudah mengakses aktivitas sehari-hari warga gampong, pembangunan jalan belum sepenuhnya terselesaikan. Pembangunan sarana jalan sudah berjalan cukup baik, namum belum semuanya dapat terselesaikan. Jadi selaku Keuchik harus bisa lebih aktif dan cakap lagi dalam proses membangun sarana dan prasarana jalan. Sarana listrik pun juga memang menjadi masalah yang dihadapi masyarakat gampong Jambak. Walaupun sempat ada masuknya proyek PLTA dan pada akhinya gagal juga. Disinalah peran serta Keuchik dan staf-stafnya untuk berusaha lebih keras lagi dalam mengusulkan tentang proyek-proyek penerangan pemukiman seperti halnya yang ada di kota-kota pula. Jadi Keuchik harus memainkan peran kepemimpinannya dalam meningkatkan sarana listrik Gampong Jambak yang memang selama ini masih sangat bergantung pada suplay PLN dan mesin-mesin dongfeng yang merupakan asset gampong.

\section{B. Saran}

Berdasarkan hasil penelitian dan kesimpulan yang dibuat oleh penulis, maka penulis memberikan saran sebagai berikut: Pemerintah Kabupaten Aceh Barat lebih merespon atau tanggap lagi kepada gampong-gampong yang berada di daerah pedalaman, sehingga semua pembangunan yang ada di gampong seluruh Kabupaten Aceh Barat ini merata tanpa pilih kasih antara gampong-gampong tertentu.

Hendaknya Keuchik sebagai pemimpin lebih aktif lagi dari sebelumnya guna dapat mencapai semua keinginan dari warga masyarakat, terutama dalam segi pembangunan fisik maupun non fisik Gampong Jambak.

Keuchik hendaknya dapat lebih memperhatikan lagi kondisi jalan Gampong yang memang sampai saat ini menjadi salah satu dari pembangunan yang belum terselesaikan. Karena dengan kondisi jalan yang seperti sekarang sangat bahaya bagi masyarkat gampong dikarenakan jalan berlubang dan licin apabila turun hujan.

Keuchik harus lebih cakap dan berusaha lebih keras lagi guna mendapatkan proyek Pembangkit Listrik Tenaga Air (PLTA) yang merupakan proyek yang berskala besar dari perusahaan. Guna meninggalkan kebiasaan masyarakat yang sudah mengakar menggunakan 
listrik PLN yang sering padam serta tagihan yang tinggi yang memang sangat memberatkan ekonomi warga yang memiliki pendapatan tidak tetap.

Keuchik harus lebih aktif lagi melakukan kerjasama atau koordinasi dengan pihak kecamatan, dan kecamatan menyampaikan ke pemerintah daerah guna melakukan pelatihanpelatihan lembaga aparat gampong dengan maksud menambah pengetahuan sumberdaya manusia yang memang masih kurang.

\section{REFERENSI}

Anonim, Undang-Undang no 06 Tahun 2014 Tentang Desa

Anonim, Undang-Undang No 23 Tahun 2014 Tentang Pemerintah Daerah, Jakarta: Sekretaris Negara Republik Indonesia

Bafadal, Ibrahim. 2003. Manajemen Peningkatan Mutu Sumber Daya Sentralisasi Menuju Desentralisasi. Bumi Aksara. Jakarta

Gunawan, Adi. 2003. Kamus Praktis Bahasa Indonesia. Kashiko. Surabaya

Kartono, Kartini, 2011. Pemimpin Dan Kepemimpinan Apakah Pemimpin Abnormal Itu, Rajawali Pers. Jakarta

Khairudin. 2000. Pembangunan Masyarakat Tinjauan Aspek Sosiologi, Ekonomi dan Perencanaan. Liberty. Yogyakarta.

Marbun, 2008. Proses Pembangunan Desa Menyongsong Tahun 2020. Erlangga. Jakarta

Moleong. J. Lexy, 2007. Metodologi Penelitian Kualitatif. Remaja Rosdakarya. Bandung

Poerwadarminta, W.J.S. 1982. Kamus Umum Bahasa Indonesia. Balai Pustaka. Jakarta.

Rivai, Veithzal. 2006. Manajemen Sumber Daya Manusia untuk Perusahaan: dari Teori Ke Praktik, Edisi Pertama, Raja Grafindo Persada. Jakarta

Siagian, Sondang. 2003. Manajemen Sumber Daya Manusia. Bumi Aksara. Jakarta

Siagian, Sondang. 2005. Administrasi Pembangunan. Bumi Aksara. Jakarta

Sugiyono, 2013. Metode Penelitian Administrasi Dilengkapi Dengan Metode R\&D. Alfabeta.

Bandung 